\title{
DISTRIBUTION OF VIBRIO ALGINOLYTICUS-LIKE SPECIES IN SHENZHEN COASTAL WATERS, CHINA
}

\author{
Ming-Xia Chen ${ }^{1,4}$, He-Yang $\mathrm{Li}^{2} *$, Gang $\mathrm{Li}^{3}$, Tian-Ling Zheng ${ }^{1} *$
}

${ }^{1}$ Key Lab of MOE for Coast and Wetland Ecosystem, School of Life Science, Xiamen University, Xiamen 361005, China; ${ }^{2}$ Third Institute of Oceanography, State Oceanic Administration, 178 Daxue Road, Xiamen 361005, China; ${ }^{3}$ Key Lab for Coastal and Atmospheric Research, PKU-HKUST Shenzhen-Hongkong Institution Industry Education Research, Shenzhen 518048, China;

${ }^{4}$ College of Chemical Engineering, Huaqiao university, 668 Jimei Road, Xiamen, 361021, China.

Submitted: July 24, 2010; Returned to authors for corrections: October 12, 2010; Approved: March 14, 2011.

\begin{abstract}
We investigated the distribution of vibrios in Shenzhen coastal waters in order to obtain valuable information for the aquaculture industry and a health warning system. Quantities of vibrios from surface waters ranged from 0 to $4.40 \times 10^{4} \mathrm{CFUs} \mathrm{mL}^{-1}$ in April (spring), while from 0 to $2.57 \times 10^{3} \mathrm{CFUs} \mathrm{mL}^{-1}$ in September (autumn); the abundance of $V$. alginolyticus-like species from surface water ranged from 0 to $6.72 \times 10^{3} \mathrm{CFUs} \mathrm{mL}^{-1}$ in April (spring) and from 0 to $1.28 \times 10^{3} \mathrm{CFUs} \mathrm{mL}^{-1}$ in September (autumn); higher counts were observed in spring. The $V$. alginolyticus-like species was dominant in Shenzhen coastal waters, with the highest abundance in the clean region (stations YMK001 and GDN064) in April, suggesting that Vibrio spp. were naturally occurring bacteria in marine environments. The correlation between the abundance of vibrios (including V. alginolyticus-like species) and environmental factors varied in different regions and different seasons. There were no vibrios detected when the salinity was less than $11.15 \%$ in the Zhujiang River estuary, which indicated that salinity played a key role in the distribution of vibrios and $V$. alginolyticus-like species.
\end{abstract}

Key words: Distribution, Vibrio alginolyticus-like species, season, Shenzhen coastal waters, China.

\section{INTRODUCTION}

Vibrios are ubiquitous in marine and estuarine water environments. Of the known Vibrio species, at least 12 are pathogenic to humans $(5,10)$. Vibrio species also represent a major causal agents in aquaculture industry $(2,4,14)$. So this genus has acquired increasing attention in recent 20 years.

As a representative of the halophilic vibrios, Vibrio alginolyticus is isolated from coastal waters and sediments all over the world $(7,9,18,20,42,44)$, and is considered to be part of the normal marine microflora. However, $V$. alginolyticus is an important bacterial pathogen of humans, causing wound infections, otitis media, otitis externa, endophthalmitis and gastrointestinal infection (11, 26, 36, 37). This bacterium also belongs to the most important opportunistic pathogens of aquatic animals, including fish,

\footnotetext{
*Corresponding Author. Mailing address: He-Yang Li, Third Institute of Oceanography, State Oceanic Administration, 178 Daxue Road, Xiamen 361005 , China.; Tel: +86-592-219-5769 Fax: +86-592-219-5769.; E-mail: heyangli@126.com / Tian-Ling Zheng, School of Life Sciences, Xiamen University, Xiamen, China, 361005.; Tel: +86-592-2183217 Fax: +86-592-2184528.; E-mail: wshwzh@xmu.edu.cn
} 
shellfish, crustaceans, coral and echinoids, causing serious disease and damage in cultured fish and important economic losses $(3,4,12,25,29)$. Several virulence factors, including the iron uptake system (28), extracellular haemolysin $(1,25)$ and proteases (40) are suggested as the major contributors to pathogenicity in this species.

In the south coast of China, $V$. alginolyticus causes large losses in the marine aquaculture industry $(21,45)$. However, studies of the distribution, dynamics of this species have rarely been addressed in China $(38,44,46)$. When we examined the diversity of vibrios in Shenzhen coastal waters, we found that V. alginolyticus-like species was the dominant Vibrio species. Since $V$. alginolyticus was the dominant vibriosis pathogen in Guangdong waters, we decided to investigate the distribution of this bacterium in order to obtain valuable information for the aquaculture industry and for a health warning system.

\section{MATERIALS AND METHODS}

\section{Bacterial strains and media}

Isolates were stored at $-20^{\circ} \mathrm{C}$ in $50 \%$ ( vol/vol) glycerol in marine broth 2216 prepared with tryptone $(5 \mathrm{~g})$ and yeast extract $(1 \mathrm{~g})$ in 1 liter of seawater (33.8\%o) and then autoclaved. The following media were used for bacterial enumeration: (i) 2216 agar, marine broth 2216 plus agar $(1.5 \%)$ (2216A); and (ii) thiosulfate citrate bile salts agar (TCBS) plus $20 \mathrm{~g} \mathrm{NaCl}$. Selected environmental isolates from the TCBS media were identified using the $16 \mathrm{~S}$ rDNA-PCR-RFLP (16S rRNA gene - polymerase chain reaction - restriction fragment length polymorphism) method and $16 \mathrm{~S}$ rDNA sequencing.

\section{Sampling methods}

The sampling sites in Shenzhen coastal waters employed in this study are shown in Fig. 1. The ten sampling positions were selected based on long-term environmental monitoring by the Shenzhen Environmental Protection Monitoring Center, which distribute along the coast and could be the representative sites to objectively reflect the environmental quality of the sea area. Stations GDN053, GDN057, GDN058, GDN060, GDN062 and GDN063 were on the west coast, while stations GDN059, GDN061, GDN064 and YMK001 were on the east coast. Surface water samples were collected at west coast stations. At stations GDN059 and GDN061 water samples were collected from $0 \mathrm{~m}$ and $10 \mathrm{~m}$ below the surface, while at stations GDN064 and YMK001 they were collected from $0 \mathrm{~m}$, $10 \mathrm{~m}$ below the surface and $1 \mathrm{~m}$ above the bottom or $20 \mathrm{~m}$ below the surface. Samples were collected in April (spring) and September (autumn) 2008. A plexiglass sampler (5 liters) (WB-PM, Beijing Purity Instrument Co., China.) was used to collect water samples. Vertical profiles of temperature, salinity and $\mathrm{pH}$ were determined using a YSI 6600 multi-parameter unit (YSI, Yellow Springs, OH). Chlorophyll-a (Chl-a) was measured as chlorophyll fluorescence in ethanol extracts of phytoplankton cells captured on Whatman GF/F filters (19). 50 $\mu \mathrm{L}, 100 \mu \mathrm{L}$ and $200 \mu \mathrm{L}$ of all samples were spread on TCBS plates, and the plates were incubated at $26 \pm 2^{\circ} \mathrm{C}$ for 24 h. $20-$ 80 clones were randomly isolated from TCBS plates from each station. Vibrios were identified using the 16S rDNA-PCRRFLP method and 16S rDNA sequence analysis. The TCBS clone counts were analyzed and the percentage of vibrios and $V$. alginolyticus in each $20-80$ clones calculated in order to obtain their abundance. The total number of culturable heterotrophic bacteria per milliliter was expressed as the average counts from two to three 2216A plates at the appropriate dilution. Fecal coliforms were enumerated using the membrane filtration method (13). The total bacterial abundance in each sample was determined using direct microscopic counts, using the SYBR Green I staining technique (33). Data from only these surface water samples were discussed in this paper.

\section{Detection of $V$. alginolyticus-like species}

After the isolates from TCBS media had been cultured on 
2216A plates, samples of each clone were placed into a $0.2 \mathrm{~mL}$ eppendorf tube with $50 \mu \mathrm{L}$ SDS-NaOH solution (SDS $1 \%, \mathrm{NaOH}$ $0.1 \mathrm{~mol} \mathrm{~L}^{-1}$ ) to allow cell lysis, and then they were 2-fold to 5-fold diluted in distilled water. The cell lysates were used as the template DNA solution for PCR amplification.

The 16S rDNA fragment was amplified using the primer set 27F (5'-AGA GTT TGA TCC TGG CTC AG-3') and 1492R (5'GGT TAC CTT GTT ACG ACT T-3') (8). The PCR mixture contained $1 \mu \mathrm{L}$ of cell lysate, each primer at $0.2 \mu \mathrm{mol} \mathrm{L}{ }^{-1}$, each deoxynucleoside triphosphate at $200 \mu \mathrm{mol} \mathrm{L}^{-1}, 5 \mu \mathrm{L}$ of $10 \times$ PCR buffer, and $2.5 \mathrm{U}$ of Taq DNA polymerase (Takara, Dalian, China). The final volume was adjusted to $50 \mu \mathrm{L}$ with distilled water. PCR amplifications were performed in a Master Cycler gradient (Eppendorf, Hamburg, Germany). The PCR reaction conditions were: denaturation at $94^{\circ} \mathrm{C}$ for $5 \mathrm{~min}, 30$ cycles of $94^{\circ} \mathrm{C}$ for $45 \mathrm{~s}, 55^{\circ} \mathrm{C}$ for $45 \mathrm{~s}$ and $72^{\circ} \mathrm{C}$ for $45 \mathrm{~s}$, plus one additional cycle with a final $10 \mathrm{~min}$ of chain elongation. The presence of PCR products and their concentrations were determined by electrophoresis of $5 \mu \mathrm{L}$ of the product on $1.0 \%$ agarose gels.

The amplified PCR products of the correct size $(1.5 \mathrm{~kb})$ were used for RFLP analysis. $5 \mu \mathrm{L}$ of PCR amplified product was digested with the restriction enzymes MspI plus RsaI (Takara, Dalian, China) at $37^{\circ} \mathrm{C}$ overnight. The resulting RFLP products were separated by gel electrophoresis on $5 \%$ polyacrylamide gels in $1 \times$ TAE with $90 \mathrm{~V}$ for $2 \mathrm{~h}$. The gel was stained with $0.5 \mu \mathrm{g} \mathrm{mL}$ 1 ethidium bromide, and visualized using UV excitation. The RFLP patterns were compared by eye.

DNA sequences of 16S rDNA of each different RFLP pattern were determined using an ABI 3730 automated sequencer according to the manufacturers' instructions (GenScript). The sequences were submitted to GenBank for comparative sequence analyses. The TCBS strains with the similarity of the 16S rDNA sequences $99 \%$ identical to $V$. alginolyticus were described as $V$. alginolyticus-like species in the present study. All partial $16 \mathrm{~S}$ rDNA sequences were deposited in the GenBank database under accession numbers GU371661 to GU371719.

\section{Statistical analysis of the results}

The results for the vibrios and $V$. alginolyticus-like isolates were then statistically analyzed to observe pearson correlations coefficient with environmental factors using Microsoft Office Excel (2007) (39).

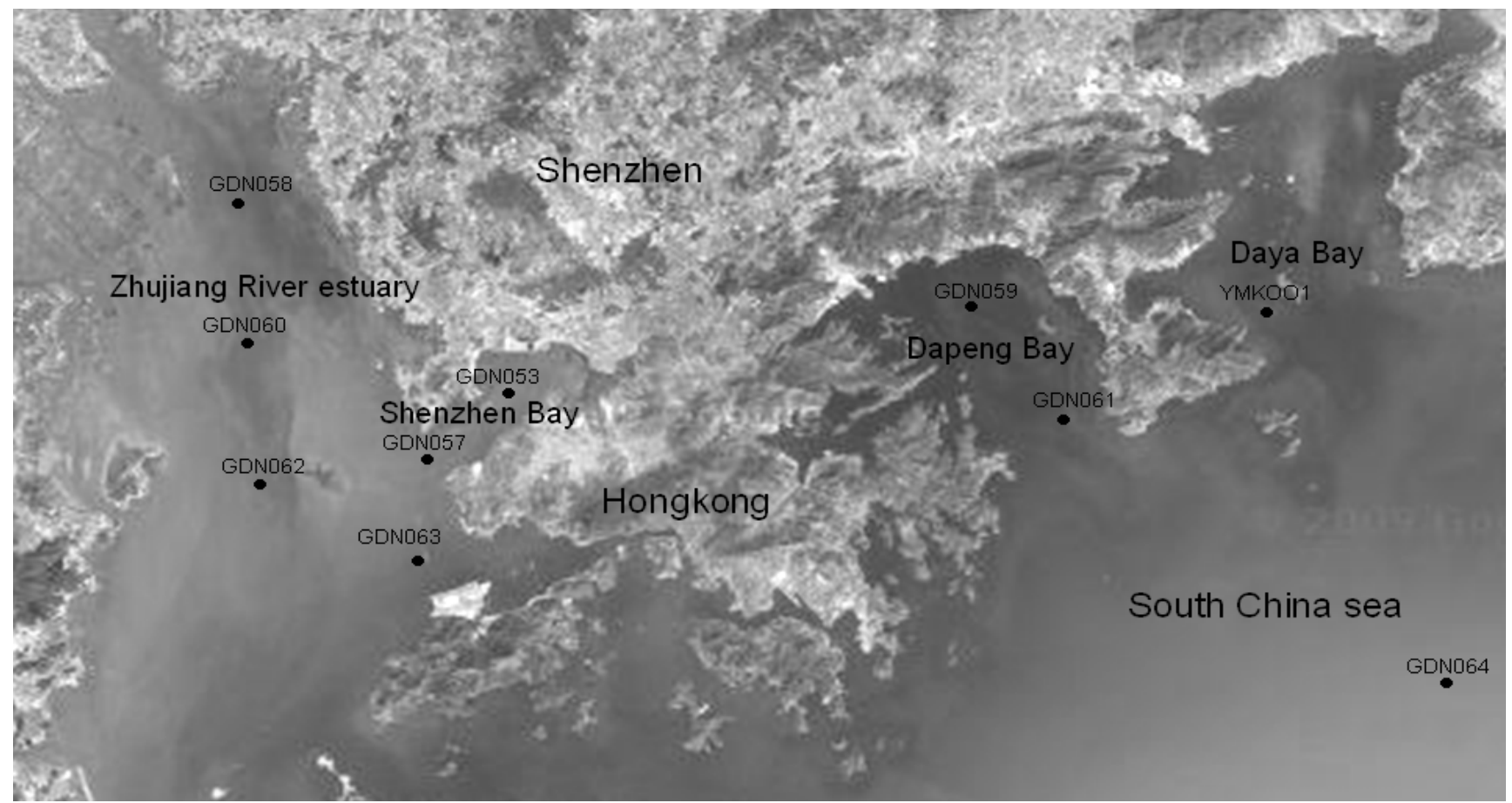

Figure 1. Shenzhen coastal waters sampling stations employed in this study 


\section{RESULTS AND DISCUSSION}

\section{Distribution of vibrios}

The total surface presumptive and culturable vibrio counts (growing on modified TCBS, TCBS numbers or TCBS clone counts) in east coast water samples were significantly higher with a mean value of $1.50 \times 10^{4} \mathrm{CFUs} \mathrm{mL}^{-1}$ when compared to that in west coast waters with a mean value of $3.35 \times 10^{2}$ CFUs $\mathrm{mL}^{-1}$ in April. However, in September, there was no significant difference in TCBS numbers: east coast samples had a mean value of $1.27 \times 10^{3} \mathrm{CFUs} \mathrm{mL}^{-1}$, and west coast samples had a mean value of $2.06 \times 10^{3}$ CFUs $\mathrm{mL}^{-1}$. Random colonies from TCBS plates (about 600 isolates from April samples and 700 isolates from September samples) were identified to the species level using the 16S rDNA-RFLP analysis method and DNA sequencing. The percentages of vibrios to TCBS numbers ranged from $42 \%$ to $100 \%$, except at stations GDN058 and GDN060 (no vibrios detected) in April, while those in September ranged from $12 \%$ to $82 \%$, except at stations GDN058, GDN060 and GDN062 (no vibrios detected). Quantities of vibrios ranged from 0 to $6.62 \times 10^{2} \mathrm{CFUs}^{-1}$ with a mean value of $2.66 \times 10^{2} \mathrm{CFUs} \mathrm{mL}^{-1}$ in west coast water and from $5.10 \times 10^{2}$ to $4.40 \times 10^{4}$ CFUs $\mathrm{mL}^{-1}$ with a mean value of $1.50 \times 10^{4} \mathrm{CFUs} \mathrm{mL}^{-1}$ in east coast water, and there were no significant difference with the TCBS clone counts in April. In September, the quantities of vibrios ranged from 0 to $1.56 \times 10^{3}$ CFUs $\mathrm{mL}^{-1}$ with a mean value of $5.09 \times 10^{2} \mathrm{CFUs}^{-1}$ in west coast waters and from $1.41 \times 10^{2}$ to $2.57 \times 10^{3} \mathrm{CFUs} \mathrm{mL}^{-1}$ with a mean value of $8.89 \times 10^{2} \mathrm{CFUs} \mathrm{mL}^{-1}$ in east coast waters, which were significantly lower than the TCBS numbers. The incidence of vibrios in different samples varied (Table 1, Fig. 2).

Analysis of the linear coefficient $(r)$ of the environmental data (Table 2, Fig. 2, Fig. 3) revealed that: (i) in April 2008, the isolation of vibrios was positively correlated with water temperature $\left(22.85^{\circ} \mathrm{C}-26.53^{\circ} \mathrm{C}\right)$, salinity $(17.18 \%$ - $33.79 \%$ o (W/V)), $\mathrm{pH}(7.77$ - 8.24), and the presence of total bacteria and culturable bacteria; but negatively correlated with the levels of fecal coliforms and Chl-a concentration; and (ii) in September 2008 , the isolation of vibrios was positively correlated with Chl-a concentration, the presence of total bacteria and culturable bacteria; and negatively correlated with levels of fecal coliforms, water temperature $\left(29.0^{\circ} \mathrm{C}-31.5^{\circ} \mathrm{C}\right)$, salinity $(19.4 \%$ - 30.81\%o ) and $\mathrm{pH}(6.33-8.71)$.

Table 1. Abundance and percentage composition of culturable vibrios at different stations $(n=20-80)$

\begin{tabular}{|c|c|c|c|c|c|c|c|c|}
\hline \multirow[b]{2}{*}{ Stations } & \multicolumn{4}{|c|}{ Apr 2008} & \multicolumn{4}{|c|}{ Sep 2008} \\
\hline & $\begin{array}{l}\text { TCBS clone } \\
\text { number } \\
\left(\text { CFUs mL } \mathbf{~}^{-1}\right)\end{array}$ & $\begin{array}{l}\text { Percentage } \\
\text { of vibrios }\end{array}$ & $\begin{array}{l}\text { No. of vibrios } \\
\left(\text { CFUs mL } \mathbf{~}^{-1}\right)\end{array}$ & $\begin{array}{c}\text { Vibrios/ } \\
\text { culturable } \\
\text { bacteria }\end{array}$ & $\begin{array}{c}\text { TCBS clone } \\
\text { number } \\
\left(\text { CFUs mL } \mathbf{m}^{-1}\right)\end{array}$ & $\begin{array}{c}\text { Percentage } \\
\text { of vibrios }\end{array}$ & $\begin{array}{l}\text { No. of vibrios } \\
\text { CFUs mL }\end{array}$ & $\begin{array}{c}\text { Vibrios/ } \\
\text { culturable } \\
\text { bacteria }\end{array}$ \\
\hline YMK001S & $4.40 \times 10^{4}$ & $100 \%$ & $4.40 \times 10^{4}$ & $11.89 \%$ & $3.13 \times 10^{3}$ & $82 \%$ & $2.57 \times 10^{3}$ & $0.88 \%$ \\
\hline GDN064S & $1.46 \times 10^{4}$ & $100 \%$ & $1.46 \times 10^{4}$ & $1.74 \%$ & $5.10 \times 10^{2}$ & $82 \%$ & $4.18 \times 10^{2}$ & $0.67 \%$ \\
\hline GDN061S & $9.60 \times 10^{2}$ & $97 \%$ & $9.31 \times 10^{2}$ & $0.73 \%$ & $3.80 \times 10^{2}$ & $37 \%$ & $1.41 \times 10^{2}$ & $0.08 \%$ \\
\hline GDN059S & $5.10 \times 10^{2}$ & $100 \%$ & $5.10 \times 10^{2}$ & $0.15 \%$ & $1.04 \times 10^{3}$ & $41 \%$ & $4.26 \times 10^{2}$ & $0.22 \%$ \\
\hline GDN053S & $7.90 \times 10^{2}$ & $70 \%$ & $5.53 \times 10^{2}$ & $1.10 \%$ & $2.52 \times 10^{3}$ & $62 \%$ & $1.56 \times 10^{3}$ & $1.44 \%$ \\
\hline GDN057S & $7.20 \times 10^{2}$ & $92 \%$ & $6.62 \times 10^{2}$ & $1.21 \%$ & $1.77 \times 10^{3}$ & $12 \%$ & $2.12 \times 10^{2}$ & $0.04 \%$ \\
\hline GDN063S & $1.50 \times 10^{2}$ & $42 \%$ & $6.30 \times 10^{1}$ & $0.09 \%$ & $5.33 \times 10^{3}$ & $24 \%$ & $1.28 \times 10^{3}$ & $0.38 \%$ \\
\hline GDN062S & $3.50 \times 10^{2}$ & $90 \%$ & $3.15 \times 10^{2}$ & $0.12 \%$ & $2.72 \times 10^{3}$ & 0 & 0 & 0 \\
\hline GDN060S & $2.00 \times 10^{1}$ & 0 & 0 & 0 & $8.50 \times 10^{1}$ & 0 & 0 & 0 \\
\hline GDN058S & $2.00 \times 10^{1}$ & 0 & 0 & 0 & $8.00 \times 10^{1}$ & 0 & 0 & 0 \\
\hline Mean value & $6.21 \times 10^{3}$ & $69 \%$ & $6.16 \times 10^{3}$ & $1.70 \%$ & $1.76 \times 10^{3}$ & $34 \%$ & $6.60 \times 10^{2}$ & $0.37 \%$ \\
\hline
\end{tabular}

$n=20-80$, which is the number of colonies used for identification from each sample. Relative error is less than $5 \%$. 


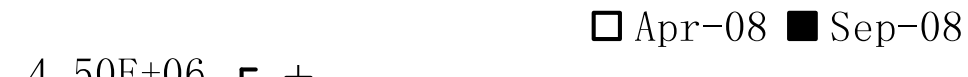

4. $50 \mathrm{E}+06$

4. $00 \mathrm{E}+06$

3. $50 \mathrm{E}+06$

3. $00 \mathrm{E}+06$

2. $50 \mathrm{E}+06$

2. $00 \mathrm{E}+06$

1. $50 \mathrm{E}+06$

1. $00 \mathrm{E}+06$

5. $00 \mathrm{E}+05$
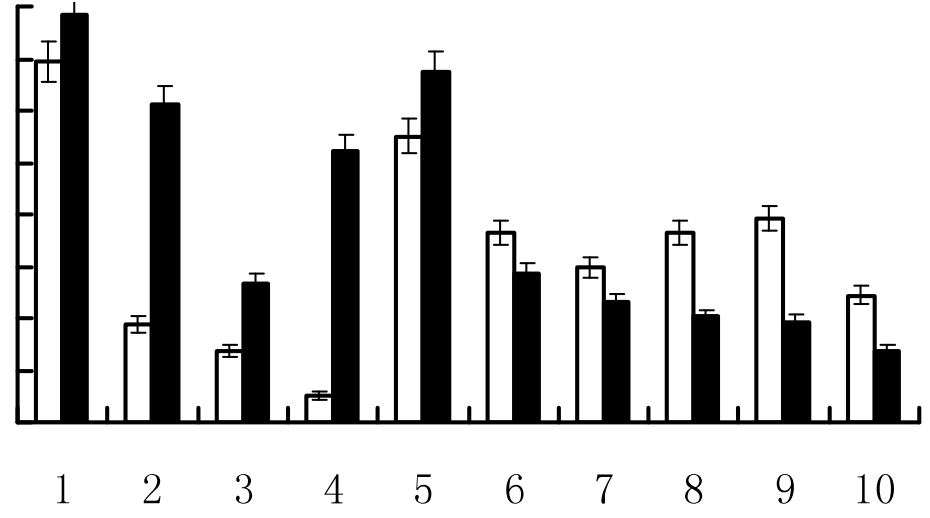

Station

B

$\square$ Apr-08 $\square$ Sep-08
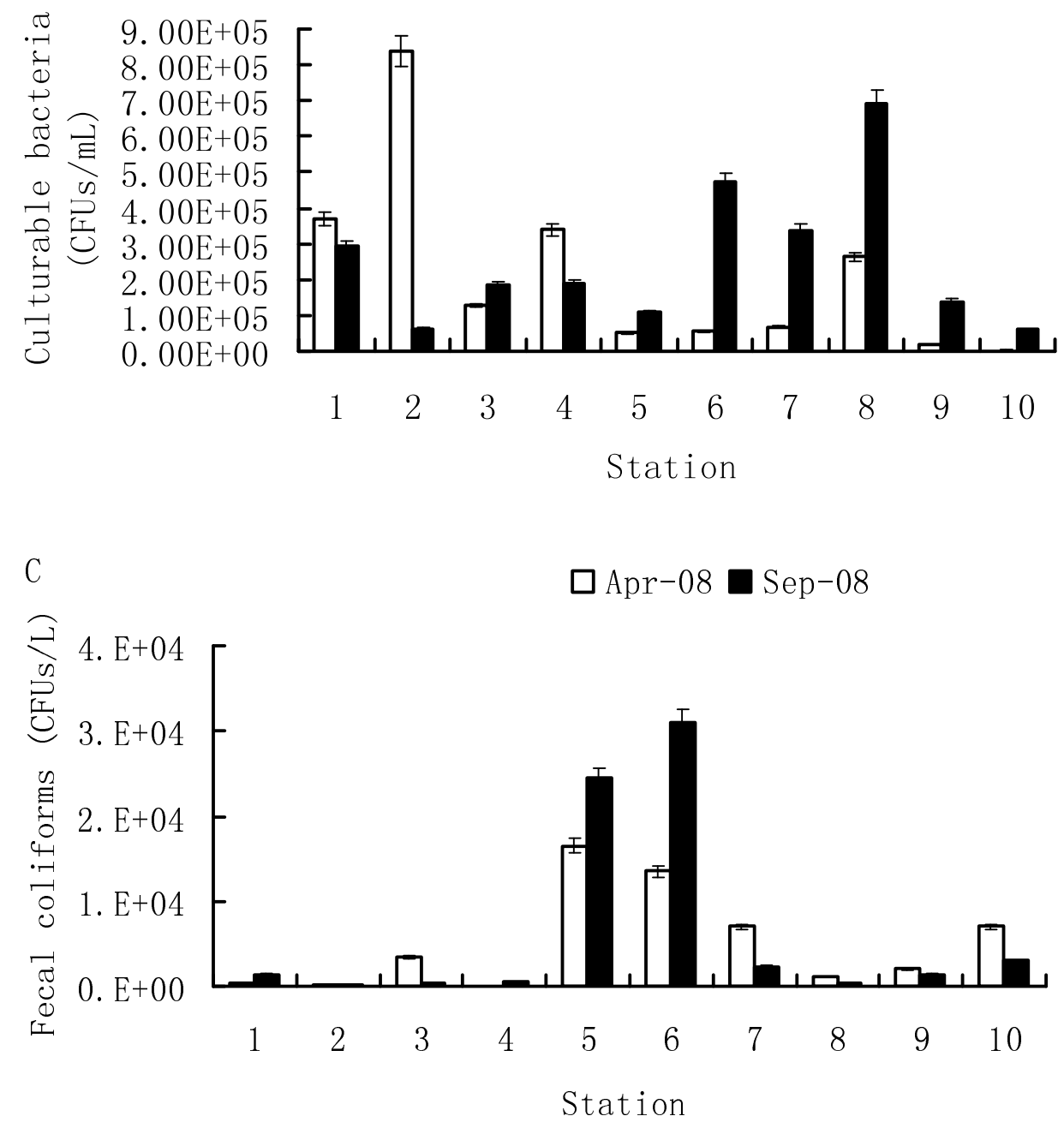

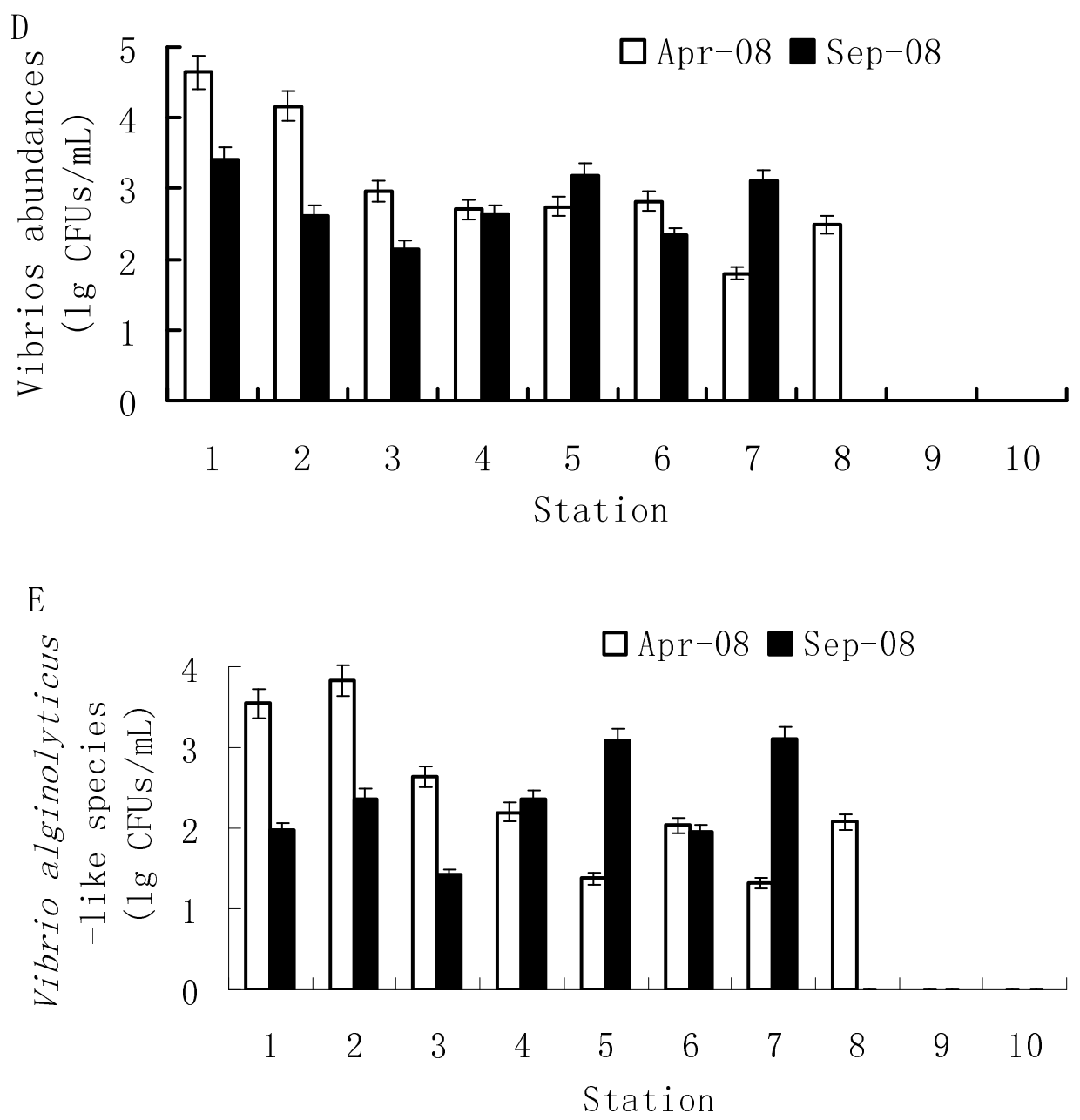

Figure 2. Relationship between the abundance of $V$. alginolyticus-like species and four other organisms parameters measured at the ten sampling sites in Shenzhen coastal waters during different seasons.

A, Total bacteria. B, Culturable bacteria. C, Fecal coliforms. D, Vibrios abundance. E, The abundance of V. alginolyticus-like species.

1, YMK001; 2, GDN064; 3, GDN061; 4, GDN059; 5, GDN053; 6, GDN057; 7, GDN063; 8, GDN062; 9, GDN060; 10 , GDN058. Error bars represent the relative errors.

Table 2. Correlation coefficient between environmental parameters and V. alginolyticus-like species and vibrios abundance

\begin{tabular}{|c|c|c|c|c|c|c|c|c|c|}
\hline & & & $\begin{array}{c}\text { Water } \\
\text { temperature }\end{array}$ & Salinity & pH & Chl-a & $\begin{array}{c}\text { Level of } \\
\text { total bacteria }\end{array}$ & $\begin{array}{c}\text { Level of } \\
\text { fecal coliforms }\end{array}$ & $\begin{array}{l}\text { Level of } \\
\text { cultureable bacteria }\end{array}$ \\
\hline \multirow{2}{*}{$\begin{array}{l}\text { Abundance of } \\
\text { V. alginolyticus }\end{array}$} & April & $\mathrm{n}=8$ & 0.6000 & $0.6400^{\mathrm{a}}$ & 0.3700 & $-0.7603^{a}$ & 0.0561 & -0.4671 & $0.9085^{\mathrm{b}}$ \\
\hline & September & $\mathrm{n}=7$ & -0.5763 & -0.5831 & $-0.8135^{\mathrm{a}}$ & 0.0429 & 0.3645 & -0.28052 & 0.3479 \\
\hline \multirow{2}{*}{$\begin{array}{c}\text { Vibrios } \\
\text { abundance }\end{array}$} & April & $\mathrm{n}=8$ & 0.1700 & 0.5301 & 0.3243 & -0.1072 & 0.5929 & -0.4063 & 0.4411 \\
\hline & September & $\mathrm{n}=7$ & -0.2488 & -0.2134 & -0.3866 & $0.7411^{\mathrm{a}}$ & 0.5788 & -0.0200 & 0.0166 \\
\hline
\end{tabular}

${ }^{\mathrm{a} P}<0.05 .{ }^{\mathrm{b}} P<0.01 . n=7$ or 8 , is the number of stations where vibrios were detected. 

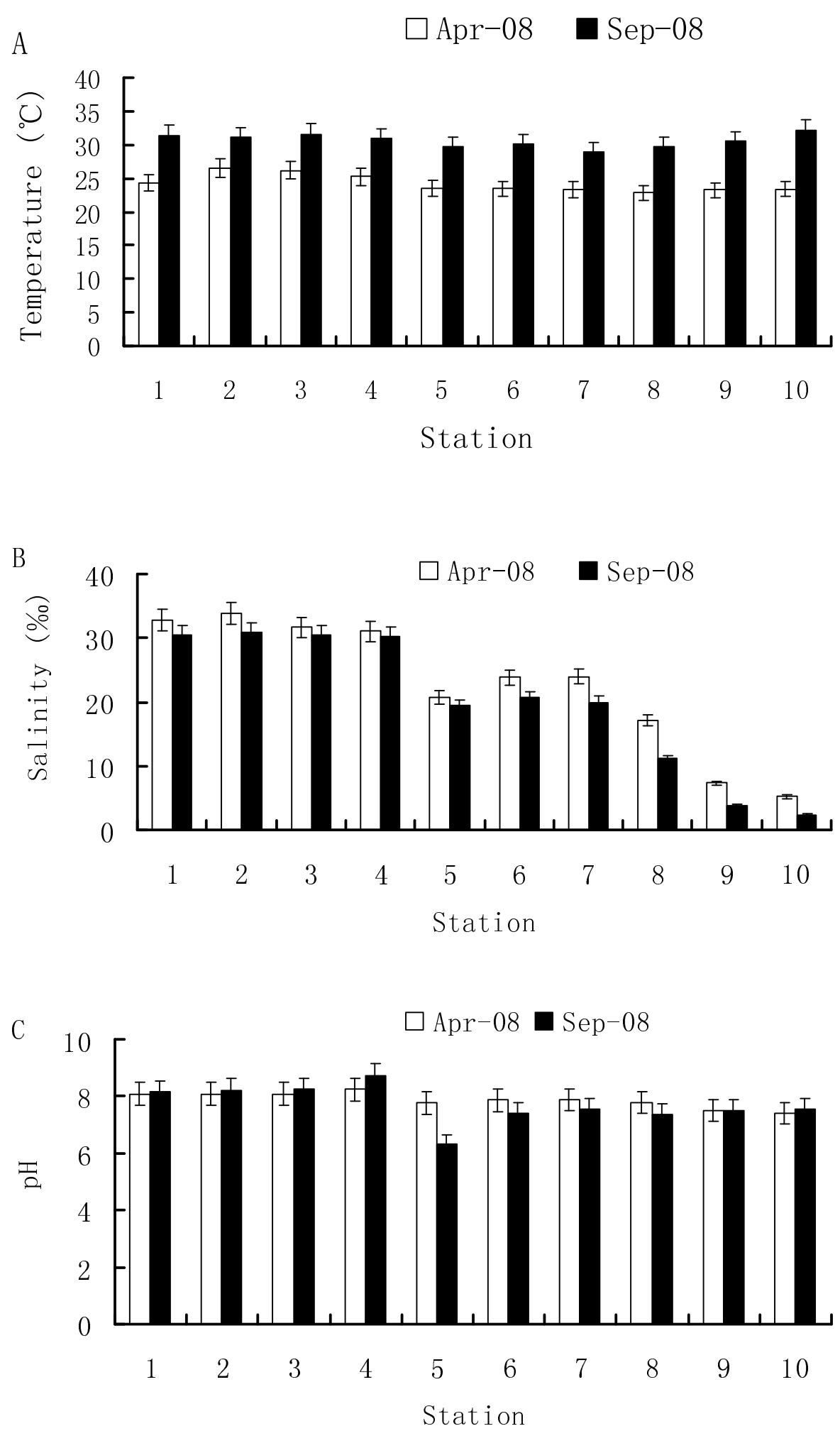


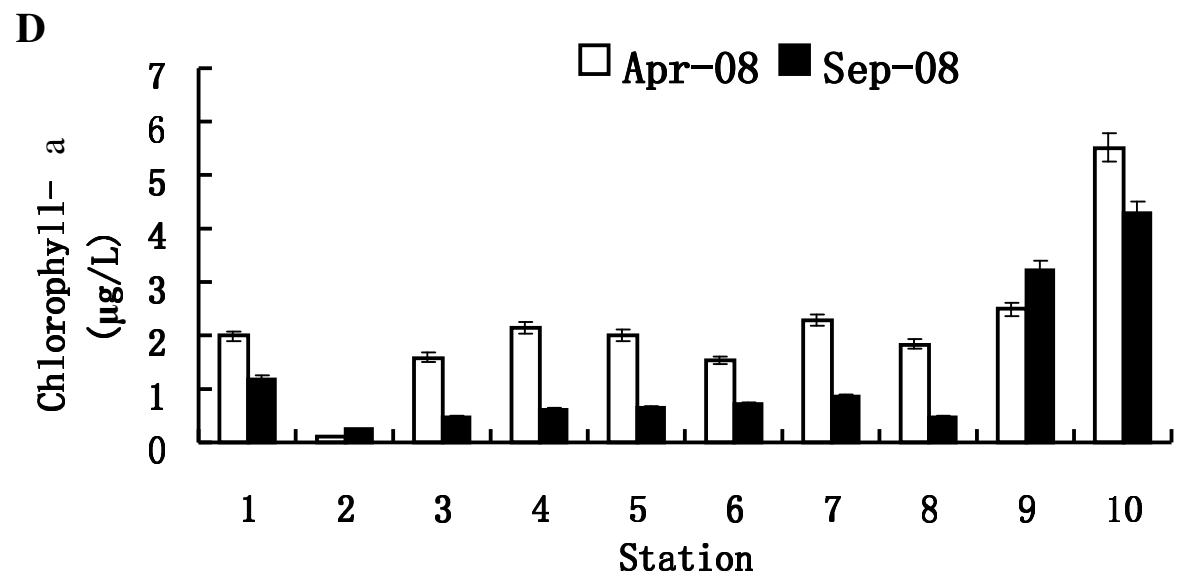

Figure 3. Four environmental parameters measured at the ten sampling sites in Shenzhen coastal waters during different seasons.

A, Water temperature. B, Salinity. C, pH. D, Chlorophyll-a concentration.

1, YMK001; 2, GDN064; 3, GDN061; 4, GDN059; 5, GDN053; 6, GDN057; 7, GDN063; 8, GDN062; 9, GDN060; 10 , GDN058. Error bars represent the relative errors.

Study (35) shows that water temperature is highly correlated to the density of vibrios. Our data indicates that seasonal variations of culturable vibrios in Shenzhen coastal waters were obvious, and the water temperature of April (average value $24.20^{\circ} \mathrm{C}$ ) seemed more acceptable for the isolation of total vibrios than that of September (average value $30.6^{\circ} \mathrm{C}$ ). Eiler et al. (9) reported that total vibrio abundances are correlated significantly with salinity $(P<0.01)$. In our study, we found that the salinity (17.18\%o-33.79\%o) was not significantly correlated $(P>0.05)$ with the distribution of vibrios. Otherwise, when the salinity was less than $11.15 \%$, no vibrios were detected.

Several authors report a considerable rise in the numbers of vibrios isolated from water samples in summer $(30,31,44)$. In contrast, and in agreement with the results of Harriague et al (16), our study showed that the mean numbers of vibrios in April was higher than that in September. Pfeffer et al. (35) report a positive correlation between Vibrio spp. and culturable bacteria in the estuarine waters of Eastern North Carolina. Table 2 shows correlations between different environmental parameters and the abundances of vibrios, which indicated that total bacteria counts were more highly and stably positively correlated with the level of vibrios.

Our results concerning the relationship between fecal coliform counts and the presence of vibrios in Shenzhen coastal waters were in agreement with the findings of other authors $(17,24,34)$. As shown in Table 2, there were negative but no statistically significant correlation $(P>0.05)$ between the two parameters. The results of our investigation also confirmed that, monitoring fecal coliform counts could not indicate the level of marine vibrios, despite the substantial amount of time and resources that go into investigating the fecal coliform parameters as required by current legislation. Thus, consumer health may not be adequately safeguarded (34). In agreement with other authors (16), we believed that to properly protect human health and to reduce the incidence of food-borne diseases due to the consumption of raw marine product, it would be advisable to carry out long-term monitoring and direct investigation of the presence and properties of Vibrio species in different coastal water compartments.

In agreement with the results of Uchiyama (42), the present study found that the percentage of vibrios to TCBS groups (bacteria grown on TCBS agar plates) changed depending on 
the samples and seasons. In the fresh or brackish region, such as Zhujiang estuary, when salinity was less than $11 \%$, there was not culturable vibrios detected, and the percentage of vibrios was $0 \%$, which indicated that there was totally no correlation between the abundance of TCBS groups and vibrios; and when salinity was above $11 \%$ o there, the percentage of vibrios was $12-92 \%$, which indicated that there was not significant correlation between the abundance of TCBS groups and vibrios. The percentage of vibrios was 37$100 \%$ in more saline sea waters, and the correlation between the abundance of TCBS groups and vibrios was significant. These results suggested that the identification of the TCBS groups is a necessary procedure to detect vibrios abundance together with TCBS agar count, expecially in fresh or brackish region. In our study, vibrios and $V$. alginolyticus-like species were identified, using TCBS agar, 16S rDNA-RFLP and 16S rDNA sequence analysis methods, which are more reliable than the classical phenotypic identification techniques (41).

\section{Distribution of $\boldsymbol{V}$. alginolyticus-like species}

Vibrios (including V. alginolyticus-like species) were readily detectable in surface water samples collected throughout Shenzhen coastal waters (except some Zhujiang River estuarine stations, where no Vibrio spp. were recovered), but compared with previous studies (23) it did not constitute a significant proportion of the total culturable heterotrophic bacterial population in samples collected during 2008 (Tables 1 and 3). The culturable heterotrophic population in seawater, enumerated on $2216 \mathrm{~A}$ medium, ranged from $2.30 \times 10^{3}$ to $8.39 \times 10^{5}$ CFUs $\mathrm{mL}^{-1}$ of surface water in April and from $6.05 \times 10^{4}$ to $6.94 \times 10^{5} \mathrm{CFUs} \mathrm{mL}^{-1}$ in September, while vibrios averaged $2.13 \%$ in April (average of the 8 stations where vibrios were detected) and $0.49 \%$ in September (average of the 7 stations where vibrios were detected) (Table 1). When detected, the numbers of $V$. alginolyticus-like species in surface water ranged from $2.10 \times 10^{1}$ to $6.72 \times 10^{3} \mathrm{CFUs} \mathrm{mL}^{-1}$ with a mean of $1.39 \times 10^{3}$ CFUs $\mathrm{mL}^{-1}$ in April (average of the 8 stations where vibrios were detected), and from $8.85 \times 10^{1}$ to $1.28 \times 10^{3} \mathrm{CFUs} \mathrm{mL}{ }^{-1}$ with a mean of $4.51 \times 10^{2} \mathrm{CFUs} \mathrm{mL}^{-1}$ in September (average of the 7 stations where vibrios were detected). These averages represented $0.31 \%$ and $0.29 \%$ of the total culturable bacterial population, $27.89 \%$ and $50.20 \%$ of the vibrio abundance, and $24.50 \%$ and $22.14 \%$ of TCBS clone counts in April and September, respectively (Table 3). Abundance of $V$. alginolyticus-like species was monitored in Shenzhen coastal water samples collected from areas with salinities ranging from $2.38 \%$ o to $33.79 \%$, as shown in Fig. 3B. When salinities ranged from $2.385 \%$ o to $11.15 \%$ in the Zhujiang River estuary, no $V$. alginolyticus-like species were recovered from any site. The abundance of $V$. alginolyticus-like species in the water was highest at station GDN064 $\left(6.72 \times 10^{3}\right.$ CFUs $\left.\mathrm{mL}^{-1}\right)$ and station YMK001 $\left(3.52 \times 10^{3}\right.$ CFUs $\left.\mathrm{mL}^{-1}\right)$ in April, and station GDN053 $\left(1.21 \times 10^{3} \mathrm{CFUs} \mathrm{mL}^{-1}\right)$ and station GDN063 (1.28 $\times 10^{3}$ CFUs $\left.\mathrm{mL}^{-1}\right)$ in September (Fig. 2E).

In agreement with previous studies in Chinese coastal waters $(15,32,44)$, we found that the $V$. alginolyticus-like species was the most frequent and dominant Vibrio species in Shenzhen coastal waters.

The correlation coefficients between environmental factors and the abundance of $V$. alginolyticus are shown in Table 2. Previous studies note significant correlation between Vibrio (including $V$. alginolyticus) abundance and water temperature at three beaches in the northern Adriatic Sea (Italy) (16) and in Ligurian Coast Rock Pools (Tyrrhenian Sea, Italy) (6). Water temperatures at our study stations were always between $22.85^{\circ} \mathrm{C}$ to $26.53^{\circ} \mathrm{C}$ in April and $29.0^{\circ} \mathrm{C}$ to $31.5^{\circ} \mathrm{C}$ in September (Fig. 3A), values within the optimal growth range for $V$. alginolyticus (10). Thus, it was likely that no significant relationship would be found between water temperature and the abundance of $V$. alginolyticus-like species. However, water temperature had a positive effect in April and a negative effect in September on the variability of $V$. alginolyticus-like species, which showed that the optimum ambient temperature for the distribution of $V$. alginolyticus-like species might be between 
$26.53^{\circ} \mathrm{C}$ and $29.0^{\circ} \mathrm{C}$ instead of the temperature that was stated to be close to the optimal growth temperature (around $36^{\circ} \mathrm{C}$ ) (43).

Eiler et al. (9) conclude that high-salinity populations (including $V$. alginolyticus) were dominant in Skagerrak Sea samples and significantly positively correlated with salinity $(P$ $<0.01)$. Salinities measured at our study stations showed no significant difference in different seasons (Fig. 3B). Table 2 shows that salinity was significantly positively correlated with the abundance of $V$. alginolyticus-like species in April but not significantly negatively correlated with that in September at stations where $V$. alginolyticus-like species were detected. The salinities in these stations were always between $17.18 \%$ and $33.79 \%$ in both seasons, values almost within the optimal growth salinity range, but the effect of the two seasons on the abundance of $V$. alginolyticus-like species was opposite. Thus, it was likely that the variability of $V$. alginolyticus-like species isolated from these water samples did not depend on the salinity $(17.18 \%$ - $33.79 \%$ ) directly. In the other hand, there were no $V$. alginolyticus-like species detected in the Zhujiang River estuary (stations GDN058 and GDNO60 in April; stations GDN058, GDNO60 and GDN062 in September), which suggested that the salinity levels between $2.38 \%$ and $11.15 \%$ at the stations were limiting to the growth of the bacterium (optimal salinity range is from $2 \%$ to $10 \%(\mathrm{~W} / \mathrm{V}$ ) (5)). This result confirmed that the species was originally in seawater unaffected by the runoff of the Zhujiang River, and that salinity was important and controlled the distribution of $V$. alginolyticus-like species to a certain degree.

Chan et al. (7), comparing their study in the subtropical coastal waters of Hongkong with a study in the coastal waters of the United States, believe that the $\mathrm{pH}$ (5.6-6.6) of the water might be one of the important environmental factors affecting the relative abundance of sucrose-negative and sucrose-positive vibrios (most of the sucrose- positive vibrios detected were $V$. alginolyticus) in coastal waters. While the statistical analyses in the present study revealed a significantly negative correlation between the abundance of $V$. alginolyticus-like species and $\mathrm{pH}(6.33-8.71)$ in September and a small positive correlation with $\mathrm{pH}$ (7.79-8.08) in April, this was understandable, since the $\mathrm{pH}$ in April varied little in different stations in the present study, which was not limiting to the growth of $V$. alginolyticus.

Hsieh et al. (20) report positive correlation between the abundance of vibrios and Chl-a, whilst the present study revealed a significantly negative correlation in April, and little positive correlation in September, between the two parameters in question. Since the concentration of Chl-a varied together (Fig. 3D) at different stations in both seasons, it seemed that the variability of $V$. alginolyticus-like species isolated from the water samples also did not depend on Chl-a directly.

Data from Chan et al. (7) indicate the positive correlations between the abundance of $V$. alginolyticus $(P<0.05)$ and both culturable bacteria and the level of fecal coliforms $(0.05<P<$ 0.1). The present study revealed no significant positive correlation with total bacteria $(P>0.1)$, small negative correlation $(P>0.1)$ with fecal coliforms, and significant positive correlation $(P<0.01)$ with culturable bacteria in April.

In summary, the correlation between the abundance of vibrios and environmental factors varied in different regions, different species and different seasons. The abundance of vibrios might have been due to the combined effect of all the environmental factors, and the correlation might not be linear. It was interesting to note that higher counts of vibrios were observed in the clean region (stations YMK001 and GDN064) in east coast waters in April when compared with the polluted west coast $(22,27)$, and there were no vibrios detected when the salinity was less than $11.15 \%$ in the Zhujiang River estuary. These results indicated that salinity was important to the distribution of vibrios (includes $V$. alginolyticus-like species) and suggested that Vibrio spp. were naturally occurring bacteria in marine environments and played a key role in the marine ecosystem. 
Table 3. Abundance and percentage composition of $V$. alginolyticus-like species at different stations $(n=20-80)$

\begin{tabular}{|c|c|c|c|c|c|c|c|c|}
\hline \multirow[b]{2}{*}{ Stations } & \multicolumn{4}{|c|}{ Apr 2008} & \multicolumn{4}{|c|}{ Sep 2008} \\
\hline & $\begin{array}{l}\text { No. of } V \text {. alginolyticus- } \\
\left.\text { like species (CFUs } \mathrm{mL}^{-1}\right)\end{array}$ & $\begin{array}{c}\text { Percentage } \\
\text { of TCBS } \\
\text { clone counts }\end{array}$ & $\begin{array}{l}\text { Percentage of } \\
\text { vibrios }\end{array}$ & $\begin{array}{c}\text { Percentage } \\
\text { of culturable } \\
\text { bacteria }\end{array}$ & $\begin{array}{l}\text { No. of } V \text {. alginolyticus- } \\
\left.\text { like species (CFUs mL }{ }^{-1}\right)\end{array}$ & $\begin{array}{l}\text { Percentage of } \\
\text { TCBS clone } \\
\text { counts }\end{array}$ & $\begin{array}{l}\text { Percentage of } \\
\text { vibrios }\end{array}$ & $\begin{array}{c}\text { Percentage } \\
\text { of culturable } \\
\text { bacteria }\end{array}$ \\
\hline YMK001S & $3.52 \times 10^{3}$ & $8 \%$ & $8.00 \%$ & $0.95 \%$ & $9.39 \times 10^{1}$ & $3 \%$ & $3.66 \%$ & $0.03 \%$ \\
\hline GDN064S & $6.72 \times 10^{3}$ & $46 \%$ & $46.00 \%$ & $0.80 \%$ & $2.35 \times 10^{2}$ & $46 \%$ & $56.10 \%$ & $0.37 \%$ \\
\hline GDN061S & $4.32 \times 10^{2}$ & $45 \%$ & $46.39 \%$ & $0.34 \%$ & $2.66 \times 10^{1}$ & $7 \%$ & $18.92 \%$ & $0.01 \%$ \\
\hline GDN059S & $1.58 \times 10^{2}$ & $31 \%$ & $31.00 \%$ & $0.05 \%$ & $2.29 \times 10^{2}$ & $22 \%$ & $53.66 \%$ & $0.12 \%$ \\
\hline GDN053S & $2.37 \times 10^{1}$ & $3 \%$ & $4.29 \%$ & $0.05 \%$ & $1.21 \times 10^{3}$ & $48 \%$ & $77.42 \%$ & $1.11 \%$ \\
\hline GDN057S & $1.08 \times 10^{2}$ & $15 \%$ & $16.30 \%$ & $0.20 \%$ & $8.85 \times 10^{1}$ & $5 \%$ & $41.67 \%$ & $0.02 \%$ \\
\hline GDN063S & $2.10 \times 10^{1}$ & $14 \%$ & $33.33 \%$ & $0.03 \%$ & $1.28 \times 10^{3}$ & $24 \%$ & $100.00 \%$ & $0.38 \%$ \\
\hline GDN062S & $1.19 \times 10^{2}$ & $34 \%$ & $37.78 \%$ & $0.05 \%$ & 0 & 0 & 0 & 0 \\
\hline GDN060S & 0 & 0 & 0 & 0 & 0 & 0 & 0 & 0 \\
\hline GDN058S & 0 & 0 & 0 & 0 & 0 & 0 & 0 & 0 \\
\hline
\end{tabular}


$V$. alginolyticus is a ubiquitous organism isolated in seawater and appears to be present in seawater in larger numbers than other Vibrio species $(15,16,18,44)$. The present study found that $V$. alginolyticus-like species was the dominant Vibrio species in Shenzhen coastal waters especially during April (Table 3). Although it accounted for only a small proportion of the bacterial populations of coastal waters in Shenzhen, it might accumulate in marine animals and cause a public health hazard when people eat uncooked or only partially cooked marine products (e.g. oysters) contaminated by the bacterium. If more relationships between the density of $V$. alginolyticus and various environmental factors can be elucidated, it may be possible to pre-warn of potential infections and vibriosis of aquaculture animals caused by this bacterium.

\section{ACKNOWLEDGMENTS}

The authors have made equal contributions to this paper. This work was supported in part by grants from the NSF of China (No: 41006117, 40930847, 40876061), the Science Foundation of the Third Oceanic Institute, State Oceanography Administration (2007021 \& 2005003), the Marine Public Welfare Project (200805064), the Special Project of Comprehensive Survey of Coastal Marine Ecology of China (908-02-04-01), the NSC of Fujian, China (Z0515011) and the Young Scientist Program of Fujian, China (2004Z055). Professor John Hodgkiss is thanked for his assistance with English.

\section{REFERENCES}

1. Aguirre-Guzmán, G.; Ruíz, H.M.; Ascencio, F. (2004). A review of extracellular virulence product of Vibrio species important in diseases of cultivated shrimp. Aquac. Res. 35(15), 1395-1404.

2. Austin, B.; Austin, D.A. (eds). (2007). Bacterial fish pathogens: disease of farmed and wild fish. 4th Ed. Springer/Prazis, Chichester.

3. Austin, B.; Stobie, M.; Robertson, P.A.W.; Glass, H.G.; Stark, J.R.; Mudarris, M. (1993). Vibrio alginolyticus: the cause of gill disease leading to progressive low-level mortalities among juvenile turbot,
Scophthalmus maximus L., in a Scottish aquarium. J. Fish Dis. 16(3), 277-280.

4. Balcázar, J.L.; Gallo-Bueno, A.; Planas, M.; Pintado, J. (2010). Isolation of Vibrio alginolyticus and Vibrio splendidus from captive-bred seahorses with disease symptoms. Antonie van Leeuwenhoek. 97(2), 207-210.

5. Baumann, P.; Schubert, R.H.W. (1984). Vibrionaceae. In: Krieg, N.R.; Holt, J.G. (eds). Bergey's manual of systematic bacteriology. 1st Ed, vol 1. The Williams \& Wilkins Co., Bmore, Md, p.516-550.

6. Carli, A.; Pane, L.; Casareto, L.; Bertone, S.; Pruzzo, C. (1993). Occurrence of Vibrio alginolyticus in Ligurian coast rock pools (Tyrrhenian Sea, Italy) and its association with the copepod Tigriopus fulvus (Fisher 1860). Appl. Environ. Microbiol. 59(6), 1960-1962.

7. Chan, K.Y.; Woo, M.L.; Lo, K.W.; French, G.L. (1986). Occurrence and distribution of halophilic vibrios in subtropical coastal waters of Hong Kong. Appl. Environ. Microbiol. 52(6), 1407-1411.

8. DeLong, E.F. (1992). Archaea in coastal marine environments. Proc. Natl. Acad. Sci. USA. 89(12), 5685-5689.

9. Eiler, A.; Johansson, M.; Bertilsson, S. (2006). Environmental influences on Vibrio populations in northern temperate and boreal coastal waters (Baltic and Skagerrak Seas). Appl. Environ. Microbiol. 72(9), 60046011.

10. Farmer III, J.J.; Janda, J.M. (2004). Vibrionaceae. In: Brenner, D.J.; Krieg, N.R.; Staley, J.T. (eds). Bergey's Manual of Systematic Bacteriology. 2nd Ed, vol 2, part B. Springer, New York, USA, p.491546.

11. Gomez, J.M.; Fajardo, R.; Patino, J.F.; Arias, C.A. (2003). Necrotizing fasciitis due to Vibrio alginolyticus in an immunocompetent patient. $J$. Clin. Microbiol. 41(7), 3427-3429.

12. Gonzalez-Escalona, N.; Blackstone, G.M.; Depaola, A. (2006). Characterization of a Vibrio alginolyticus strain isolated from Alaskan oyster carrying a hemolysin gene similar to the thermostable direct hemolysin-related hemolysin gene (trh) of Vibrio parahaemolyticus. Appl. Environ. Microbiol. 72(12), 7925-7929.

13. Greenberg, A.E.; Clesceri L.S.; Eaton A.D. (eds). (1992). Standard Methods for the Examination of Water and Wastewater. Amer. Public Health Assoc. Washington, D.C.

14. Haldar, S.; Maharajan, A.; Chatterjee, S.; Hunter, S.A.; Chowdhury, N.; Hinenoya, A.; Asakura, M.; Yamasaki, S. (2010). Identification of Vibrio harveyi as a causative bacterium for a tail rot disease of sea bream Sparus aurata from research hatchery in Malta. Microbiol. Res. 165(8), 639-648.

15. Han, S.; Yu, J.; Jiang, T.; Wang, D. (2008). Distribution of bacteria in brine of southeast China coastal area. J. Prev. Med. Chin. PLA. 26(1), 18-21.

16. Harriague, A.C.; Brino, M.D.; Zampini, M.; Albertelli, G.; Pruzzo, C.; Misic, C. (2008). Vibrios in association with sedimentary crustaceans in three beaches of the northern Adriatic Sea (Italy). Mar. Pollut. Bull. 56(3), 574-579. 
17. Harwood, V.J.; Gandhi, J.P.; Wright, A. (2004). Methods for isolation and confirmation of Vibrio vulnificus from oysters and environmental source: a review. J. Microbiol. Methods. 59(3), 301-316.

18. Hervio-Heath, D.; Colwell, R.R.; Derrien, A.; Robert-Pillot, A.; Fournier, J.M.; Pommepuy, M. (2002). Occurrence of pathogenic vibrios in coastal areas of France. J. Appl. Microbiol. 92(6), 1123-1135.

19. Holm-Hansen, O.; Riemann, B. (1978). Chlorophyll- $\alpha$ determination: improvements in methodology. Oikos. 30(3), 438-447.

20. Hsieh, J.L.; Fries, J.S.; Noble, R.T. (2007). Vibrio and phytoplankton dynamics during the summer of 2004 in a eutrophying estuary. Ecol. Appl. 17(5 suppl), S102-S109.

21. Hu, X.F.; Shi, C.B.; Pan, H.J.; Li, N.Q.; Wu, S.Q. (2005). Preliminary studies on the pathogen (Vibrio alginolyticus) of the ulceration disease of maricultured estuary cod, Epinephelus coioides. Periodical Ocean Univer. China. 35(2), 232-236.

22. Huang, Y.; Wang, Y.; Zhang, L. (2006). Environmental quality assessment of water body and sediment in coast in Shenzhen city. Mar. Environ. Sci. 25(4), 28-32.

23. Kaneko, T.; Colwell, R.R. (1973). Distribution of Vibrio parahaemolyticus and related organisms in the Atlantic ocean off South Carolina and Georgia. Appl. Microbiol. 28(6), 1009-1017.

24. Kong, R.Y.C.; Lee, S.K.Y.; Law, T.W.F.; Law, S.H.W.; Wu, R.S.S. (2002). Rapid detection of six types of bacterial pathogens in marine waters by multiplex PCR. Water Res. 36(11), 2802-2812.

25. Lee, K.K.; Yu, S.R.; Chen, F.R.; Yang, T.I.; Liu, P.C. (1996). Virulence of Vibrio alginolyticus isolated from diseased tiger prawn, Penaeus monodon. Curr. Microbiol. 32(4), 229-231.

26. Li, X.C.; Xiang, Z.Y.; Xu, X.M.; Yan, W.H.; Ma, J.M. (2009). Endophthalmitis Caused by Vibrio alginolyticus. J. Clin. Microbiol. 47(10), 3379-3381.

27. Lin, Q.; Yan, S.; He, L. (2001). Survey and evaluation on environmental quality of coastal area in Shenzhen. Mar. Environ. Sci. 20(3), 46-50.

28. Litwin, C.M.; Calderwood, S.B. (1993). Role of iron in regulation of virulence genes. Clin. Microbiol. Rev. 6(2), 137-149.

29. Liu, P.C.; Lin, J.Y.; Hsiao, P.T.; Lee, K.K. (2004). Isolation and characterization of pathogenic Vibrio alginolyticus from diseased cobia Rachycentron canadum. J. Basic. Microbiol. 44(1), 23-28.

30. Maeda, T.; Matsuo, Y.; Furushtta, M.; Shiba, T. (2003). Seasonal dynamics in a coastal Vibrio community examinedby a rapid clustering method based on 16S rDNA. Fish. Sci. 69(2), 385-394.

31. Mahmud, Z.H.; Neogi, S.B.; Kassu, A.; Huong, B.T.M.; Jahid, I.K.; Islam, M.S.; Ota, F. (2008). Occurrence, seasonality and genetic diversity of Vibrio vulnificus in coastal seaweeds and water along the Kii Channel, Japan. FEMS Microbiol. Ecol. 64(2), 209-218.

32. Meng, F.; Zhu, Y.; Ai, Y. (2000). Isolation, identification and serology of aquatic pathogenic Vibrios from Zhujiang entrence rims of the South
China sea. Acta Scientiarum Naturalium Univer. Sunyatsent. 39(suppl 2), 59-62.

33. Noble, R.T.; Fuhrman, J.A. (1998). Use of SYBR Green I for rapid epifluorescence counts of marine viruses and bacteria. Aquat. Microb. Ecol. 14(2), 113-118.

34. Normanno, G.; Parisi, A.; Addante, N.; Quaglia, N.C.; Dambrosio, A.; Montagna, C.; Chiocco, D. (2006). Vibrio parahaemolyticus, Vibrio vulnificus and microorganisms of fecal origin in mussels (Mytilus galloprovincialis) sold in the Puglia region (Italy). Int. J. Food Microbiol. 106(2), 219-222.

35. Pfeffer, C.S.; Hite, M.F.; Oliver, J.D. (2003). Ecology of Vibrio vulnificus in estuarine waters of eastern-north Carolina. Appl. Environ. Microbiol. 69(6), 3526-3531.

36. Reina, J.; Fernandez-Baca, V.; Lopez, A. (1995). Acute gastroenteritis caused by Vibrio alginolyticus in an immunocompetent patient. Clin. Infect. Dis. 21(4), 1044-1045.

37. Reina Prieto, J.; Heravs Palazon, J. (1993). Otitis media due to Vibrio alginolyticus: the risks of the Mediterranean Sea. An. Esp. Pediatr. 39(4), 361-363.

38. Ren C.; Hu, C.; Luo, P.; Chen, C.; Jiang, X.; Wang, Q. (2008). Genotyping of Vibrio alginolyticus isolates from Daya bay by infrequentrestriction-site PCR and pulsed-field gel electrophoresis. Mol. Cell. Probes. 22(4), 267-271.

39. Rodgers, J.L.; Nicewander, W.A. (1988). Thirteen ways to look at the correlation coefficient. Amer. Statist. 42(1), 59-66.

40. Rui, H.; Liu, Q.; Wang, Q.; Ma, Y.; Liu, H.; Shi, C.; Zhang, Y. (2009). Role of alkaline serine protease, asp, in Vibrio alginolyticus virulence and regulation of its expression by luxO-luxR regulatory system. $J$. Microbiol. Biotechnol. 19(5), 431-438.

41. Thompson, F.L.; Iida, T.; Swings, J. (2004). Biodiversity of vibrios. Microbiol. Mol. Biol. Rev. 68(3), 403-431.

42. Uchiyama, H. (2000). Distribution of Vibrio species isolated from aquatic environments with TCBS agar. Environ. Health Prev. Med. 4(4), 199204.

43. Ulitzur, S. (1974). Vibrio parahaemolyticus and Vibrio alginolyticus: Short Generation-Time Marine Bacteria. Microb. Ecol. 1, 127-135.

44. Wu, J.; Cai, C.; Zhou, Y.; Wu, Z. (2006). Variations of vibrios and heterotrophic bacteria in the caged-culture waters in Daya Bay. $J$. Zhanjiang Ocean. Univ. 26(3), 21-25.

45. Xie, Z.Y.; Hu, C.Q.; Chen, C.; Zhang, L.P.; Ren, C.H. (2005). Investigation of seven Vibrio virulence genes among Vibrio alginolyticus and Vibrio parahaemolyticus strains from the coastal mariculture systems in Guangdong, China. Lett. Appl. Microbiol. 41(2), 202-207.

46. Zhou, S.; Hou, Z.; Li, N.; Qin, Q. (2007). Development of a SYBR Green I real-time PCR for quantitative detection of Vibrio alginolyticus in seawater and seafood. J. Appl. Microbiol. 103(5), 1897-1906. 